\title{
ASSESSMENT OF BURNOUT AMONG TEACHERS DURING THE COVID-19 PANDEMIC
}

\author{
Dumitru CHEPTEA $^{1 凶}$, Raisa DELEU ${ }^{1}$, Victor MESINA ${ }^{1}$, Grigore FRIPTULEAC ${ }^{1}$, \\ Serghei CEBANU ${ }^{1}$
}

1 "Nicolae Testemitanu" State University of Medicine and Pharmacy, Chisinau, Republic of Moldova

Received 01 March 2021, Accepted 14 May 2021

https://doi.org/10.31688/ABMU.2021.56.2.06

\begin{abstract}
Introduction. The closure of schools and the transition to online teaching, results of the restrictions imposed by COVID-19 pandemic, have led to major changes in the work environment, as well as the emergence of various negative manifestations on teacher's health, such as burnout.
\end{abstract}

The objective of the study was the assessment of burnout among teachers during the COVID-19 pandemic in the Republic of Moldova.

Material and methods. A two-stage research questionnaire was applied on a sample of 375 teachers. As a result of the influence of pandemic restrictions, the occurrence of burnout was investigated using Maslach Burnout Inventory.

Results. We found significant relationships between some demographic variables and the burnout. It has also been shown that women are more susceptible to burnout than men. Occupational stress and poor working conditions, as well as the absence of physical contact with students, are strong predictors of burnout, work experience being the only protective factor.

Conclusions. The sudden change in physical working conditions, as well as the need to quickly change the teaching methods because of the COVID-19 pandemic,

\section{Résumé}

Évaluation du surmenage professionnel chez les enseignants pendant la pandémie du COVID-19

Introduction. La fermeture des écoles et la transition vers l'enseignement en ligne, en raison des restrictions imposées par la pandémie du COVID-19, ont conduit à des changements majeurs dans le milieu de travail, ainsi qu'à l'émergence de diverses manifestations négatives sur la santé des enseignants, comme l'épuisement professionnel.

L'objectif de l'étude était d'évaluer l'épuisement professionnel des enseignants pendant la pandémie de COVID-19 en République de Moldova.

Matériel et méthodes. Un questionnaire de recherche en deux étapes a été appliqué à un échantillon de 375 enseignants. En raison de l'influence des restrictions pandémiques, la survenue de l'épuisement professionnel a été étudiée à l'aide de Maslach Burnout Inventory.

Résultats. Nous avons trouvé des relations significatives entre certaines variables démographiques et l'épuisement professionnel. Il a également été démontré que les femmes sont plus sujettes à l'épuisement professionnel que les hommes. Le stress au travail et les 
have a negative impact, increasing the incidence of burnout in teachers.

Keywords: burnout, COVID-19 pandemic, teachers, occupational environment.

\section{List of abbreviations}

SARS-CoV-2 - Severe acute respiratory syndrome coronavirus 2

MBI - The Maslach Burnout Inventory

SD - Standard deviation

IES-R-Impact of Event Scale - Revised

\section{INTRODUCTION}

The COVID-19 pandemic has led to many changes in society, including education, where teachers were affected cognitively and emotionally. The distance learning engagement has clearly been one of the most prominent changes required from teachers ${ }^{1,2}$.

School closure was not a new phenomenon in education. The $2009 \mathrm{flu}$ pandemic has closed many schools around the world ${ }^{1}$. Research on the impact of school closures caused by pandemic was focused on the effectiveness of that measure in controlling the spread of the disease. The effect of school closure on student learning and well-being was also investigated ${ }^{3}$ while its effect on teachers was completely ignored. This constitutes an important research gap, because teachers are an essential workforce in all societies ${ }^{1,4}$.

On March 15, 2020, after the announcement of a national lockdown, schools in the Republic of Moldova were closed to all the students. Teachers and auxiliary school workers became vulnerable. Before that day, schools in 137 countries were closed due to the COVID-19 pandemic ${ }^{5}$. School closure affected 1.5 billion students worldwide. In the Republic of Moldova, 331100 primary and secondary students and over 34157 teachers were affected ${ }^{6}$.

Recent research has shown that between $40-50 \%$ of adults have reported various forms of psycho-emotional impairment following quarantine due to COVID-197-9 and 30\% of adults and children are at high risk of showing symptoms of post-traumatic stress disorder ${ }^{10}$. These results are consistent with those collected from Chinese studies ${ }^{7,11,12}$ and extend our knowledge regarding the psychological burden of quarantines from previous experiences of isolation due to public health emergencies ${ }^{13}$.

During the COVID-19 pandemic, research was focused mainly on general medical complications of the disease ${ }^{14,15}$ and only a few studies focused on direct impact of SARS-CoV-2 on occupational burnout. In mauvaises conditions de travail, ainsi que l'absence de contact physique avec les étudiants, sont de puissants prédicteurs d'épuisement professionnel, l'expérience de travail étant le seul facteur de protection.

Conclusions. Le changement brusque des conditions physiques de travail, ainsi que la nécessité de changer rapidement les méthodes d'enseignement en raison de la pandémie COVID-19, ont un impact négatif, augmentant l'incidence de l'épuisement professionnel chez les enseignants.

Mots-clés: épuisement, pandémie COVID-19, enseignants, environnement professionnel.

teachers, occupational burnout is a condition where a teacher has reached his mental, emotional and physical limits ${ }^{13,16,17}$. Teachers have become more exhausted and anxious because of the restrictions imposed by the pandemic, especially because of change of classical teaching methods into online/ remote teaching $^{7,18}$. Moreover, many studies carried out during this tough period showed a greater vulnerability among female teachers in terms of experiences and consequences of burnout than men ${ }^{14,19}$. Previous studies have shown unfavorable changes in women in terms of exposing mental overload and work-family conflicts ${ }^{9,19,20}$. These changes seem related to the way of working online and the gender-related inequality in the distribution of family duties. Working from home increases the number of working hours ${ }^{20}$ and blurs the boundaries between private/family life and work. In case of women, the daily program is restructured according to the family needs, which can be explained from the perspective of traditional gender roles. According to this perspective, women are responsible for most of family duties, thus generating an overload of work in both family and professional areas. In addition, women had to deal with high levels of stress in both areas, because of the incapacity to manage all tasks and duties, which often leads to the consideration of the option of leaving work or giving up the profession ${ }^{21}$.

Some teachers may have competing responsibilities, such as spending online lessons at home with their own children, caring for vulnerable family members and/or managing their own mental health. All these are parallel to the process of distance teaching and to the continuation of the methodical elements of the profession. Therefore, these conditions can present a very stressful situation for female teachers.

The OBJECTIVE OF THIS STUDY was the assessment of burnout among teachers during the COVID-19 pandemic. 


\section{Material AND MEthods}

The present study was approved by the Ethics Committee of "Nicolae Testemitanu" State University of Medicine and Pharmacy, Chisinau, Republic of Moldova (Decision no. 17 from 14.04.2019). A prospective study was used to assess the burnout syndrome in teachers during the pandemic. The data were collected using a questionnaire consisting of several items, such as personal data, characteristics of the occupational and living environments, food status, state of health. The questionnaire was applied to teachers who meet the following participation criteria: teachers from primary and general secondary education institutions who have signed informed consent and agreed to complete the questionnaire; persons of any gender (men, women); persons from urban and rural areas without ethnic restrictions; persons up to 63 years old.

\section{Sample characteristics}

375 out of 500 teachers completed a structured survey. The sample consisted of teachers, department heads and principals from a single school board. Six months later, another almost identical questionnaire was sent to all respondents. Of the 375 surveys sent, 173 were completed and returned. This represented a response rate of $46 \%$.

\section{Study variables}

The tests applied at both research times were approximately identical. Each indicator investigated had several elements with reliability of internal consistency (Cronbach's alpha) that exceeded 0.70 in almost all cases. Low reliability was expected for some indicators, due to the nature of a certain variable (such as physical health).

\section{Assessment of psychological burnout}

The Maslach Burnout Inventory (MBI) was used to assess the level of burnout ${ }^{20}$. The instrument measures three constructs: Emotional Exhaustion (EE) (9 items), Depersonalization (DP) (5 items) and Lack of Personal Accomplishments (8 items). Thus, a high level of burnout involves subjects getting high scores on exhaustion subscales (e.g., I feel exhausted from work, I feel like I am run out of power), and depersonalization (e.g., I do not really care about what happens to some of my students).

\section{Assessment of occupational stress}

To assess the level of occupational stress, the "Impact of Event Scale - Revised (IES-R)" tool was applied ${ }^{21}$, which is a short self-report questionnaire that is easy to administer, it has 22 questions. The tool, an appropriate instrument to measure the subjective response to a specific traumatic event in the older adult population, especially in the response sets of intrusion (intrusive thoughts, nightmares, intrusive feelings and imagery, dissociative-like re-experiencing), avoidance (numbing of responsiveness, avoidance of feelings, situations, and ideas), and hyperarousal (anger, irritability, hypervigilance, difficulty concentrating, heightened startle), as well as a total subjective stress IES-R score.

\section{Statistical analysis}

Descriptive statistics were initially used to give a general characteristic of the sample, after which two sets of analyses were performed. In the block, the correlation between the antecedents of psycological burnout measured at Time 1, and the three components of burnout (emotional exhaustion, depersonalization, lack of personal accomplishment) and the total MBI score measured at Time 2. The second block included the correlation between post-pandemic occupational stress and the total MBI score measured at Time 1 and the three components of the burnout measured at Time 2 .

Table 1. Age distribution, job profile, and work conditions of participants $(\mathrm{n}=375)$.

\begin{tabular}{|c|c|}
\hline Variable & Frequency (\%) \\
\hline $\begin{array}{c}\text { Age } \\
21-30 \text { years } \\
31-40 \text { years } \\
21-30 \text { years } \\
41-50 \text { years } \\
51-62 \text { years }\end{array}$ & $\begin{array}{c}51(13.2) \\
162(42.6) \\
106(27.9) \\
40(10.3) \\
16(4.4) \\
\end{array}$ \\
\hline $\begin{array}{c}\text { Job profile } \\
\text { Primary school teacher } \\
\text { Biology } \\
\text { Chemistry } \\
\text { The civic education teacher } \\
\text { Physical education teacher } \\
\text { Physics } \\
\text { Geography } \\
\text { Informatics } \\
\text { History } \\
\text { Romanian Language and } \\
\text { Literature } \\
\text { Foreign language } \\
\text { Mathematics } \\
\end{array}$ & $\begin{array}{c}71(19.1) \\
22(5.9) \\
16(4.4) \\
6(1.5) \\
6(1.5) \\
28(7.4) \\
11(2.9) \\
28(7.4) \\
33(8.7) \\
28(7.4) \\
44(11.7) \\
82(22.1)\end{array}$ \\
\hline $\begin{array}{c}\text { Work environment } \\
\text { Convenient* } \\
\text { Inconvenient** } \\
\text { No permanent workplace }{ }^{* * *}\end{array}$ & $\begin{array}{c}254(67.6) \\
105(27.9) \\
16(4.4) \\
\end{array}$ \\
\hline \multicolumn{2}{|c|}{$\begin{array}{l}\text { * the conditions of the occupational environment are in accord- } \\
\text { ance with the hygienic norms and the worker does not detect any } \\
\text { inconvenience. } \\
\text { ** the conditions of the occupational environment exceed the } \\
\text { conformity of the hygienic norms and the worker does not notice } \\
\text { discomfort due to physical factors } \\
* * * \text { refers to teachers who do not own a cabinet and are forced to } \\
\text { spend lessons in different cabinets. }\end{array}$} \\
\hline
\end{tabular}


Table 2. Mean, standard deviations (SD), and latent correlation between all factors.

\begin{tabular}{|c|c|c|c|c|c|c|c|c|c|c|c|c|}
\hline & Mean & S.D. & 1 & 2 & 3 & 4 & 5 & 6 & 7 & 8 & 9 & 10 \\
\hline \multicolumn{13}{|l|}{ Time 1} \\
\hline 1. Gender ${ }^{\mathrm{A}}$ & 1.42 & 0.49 & - & & & & & & & & & \\
\hline $\begin{array}{l}\text { 2. Years of professional } \\
\text { experience }\end{array}$ & 17.32 & 10.98 & $0.18^{*}$ & - & & & & & & & & \\
\hline $\begin{array}{l}\text { 3. Work conditions } \\
\text { (Decreased free time; } \\
\text { Increasing the time prepara- } \\
\text { tion for one lesson) }\end{array}$ & 4.34 & 3.21 & $0.05^{*}$ & -0.024 & - & & & & & & & \\
\hline 4. Occupational stress & 11,87 & 4.99 & $0.013^{* *}$ & $-0.03^{*}$ & $0.15^{*}$ & - & & & & & & \\
\hline 5. Emotional exhaustion & 21.95 & 9.90 & $-0.18^{*}$ & $-0.029^{*}$ & $0.343^{* *}$ & $0.11^{* *}$ & - & & & & & \\
\hline 6. Depersonalization & 9.54 & 6.87 & 0.03 & 0.024 & 0.218 & $-0.31^{* *}$ & 0.35 & - & & & & \\
\hline 7. Personal accomplishment & 24.86 & 9.43 & $0.01^{*}$ & -0.23 & $0.191^{*}$ & $0.38^{* *}$ & -0.39 & $-0.42^{* *}$ & - & & & \\
\hline \multicolumn{13}{|l|}{ Time 2} \\
\hline 8. Emotional exhaustion & 21.3 & 12.3 & 0.03 & $-0.011^{*}$ & $0.38^{* *}$ & $0.268^{*}$ & $0.530^{* *}$ & $0.652^{* *}$ & $0.315^{* *}$ & - & & \\
\hline 9. Depersonalization & 12.4 & 9.02 & $0.30^{* *}$ & 0.01 & $0.05^{*}$ & $0.215^{*}$ & $0.652^{*}$ & 0.52 & $0.281^{*}$ & 0.42 & - & \\
\hline $\begin{array}{l}\text { 10. Personal accomplish- } \\
\text { ment }\end{array}$ & 26.76 & 11.23 & -0.01 & -0.03 & $0.44^{* *}$ & $0.191^{*}$ & $0.315^{* *}$ & $0.281^{*}$ & $0.720^{*}$ & $-0.59^{* *}$ & $-0.35^{* *}$ & - \\
\hline
\end{tabular}

\section{Results}

We received responses from 375 teachers. Most of them were females (94.7\%). The mean age of respondents was $41 \pm 6.2$ years, with a mean number of $17.3 \pm 1.5$ years of professional experience. Among them, $60.5 \%$ worked in gymnasiums, $34.2 \%$ in high schools and $5.2 \%$ in primary schools. Most respondents (86.8\%) had bachelor's degrees and only $2.9 \%$ of them have postgraduate studies. Most of respondents $(67.4 \%)$ live in rural areas and $32.4 \%$ in urban areas. $82.4 \%$ of teachers are married, $4.4 \%$ divorced, $10.3 \%$ unmarried and $2.9 \%$ widows. $10.5 \%$ do not have children, while $89.5 \%$ of teachers have in their custody on average two children each. The sample distribution is shown on Table 1.

To investigate the connection between the main predictors of burnout, six statistical correlations were undertaken. The first block of analyses included demographic data, as well as other situational variables that served as control variants $(\mathrm{N}=5)$. The second block was the measured values of post-pandemic occupational stress $(\mathrm{N}=15)$. The third block included the values of psychological burnout at Time 1, as well as the total values of MBI $(\mathrm{N}=22)$. This analysis plan considers the increase in variance explained in a given dependent variable when other blocks of variables have been previously introduced as a predictor. The results are reflected in Table 2 .

A correlational analysis revealed significant relationships between some demographic variables (eg, gender, age, and years of professional experience) and burnout. Because age is confused with years of experience, we decided to focus on that. Therefore, we analysed gender and years of experience in subsequent analyses. Gender was negatively associated with emotional exhaustion at Time 1 and positively related to personal achievement at Time 1 , indicating that women reported greater exhaustion, but less personal achievement than men. However, women showed lower depersonalization than men at Time 2. In addition, years of experience were negatively associated with occupational stress, but were positively associated with depersonalization at Time 1 . This demonstrates that more experienced employees report lower levels of stress than their less experienced counterparts, which actually leads us to believe that this predictor is a protective factor in burnout. They also showed a greater depersonalization at Time 2, which confirms the idea that with the experience, the professional expectations of one's own person increase in direct proportion.

\section{Discussion}

Although it has long been known that high-contact workplaces, which characterize the current work conditions of teachers, pose an increased risk of the spread of acute respiratory disease, the impact of the COVID-19 pandemic on teacher's health has not yet been investigated ${ }^{18}$.

The period of isolation due to the spread of COVID-19 has negative effects on the psychological state of the world's population. This has been explained by several researchers, including on various samples of teachers either tested positive or not for the new type of virus. This in turn led to the faster 
and more pronounced installation of occupational burnout syndrome in this category of population ${ }^{10,12,17}$.

As in previous research, our study highlighted the main predictors of burnout due to COVID-19 pandemic. Analysing the obtained data, it is possible to mention about the major impact of the occupational environment on psychological burnout syndrome, both as an immediate response to its modification and its amplification in time, a phenomenon also explained by Pizov in his study ${ }^{22}$. A negative influence on the psychological state of the teachers also demonstrated the decrease of free time, this being mostly occupied by the preparations for the next lessons, a fact also identified by Brooks et $\mathrm{al}^{13}$.

The emotional exhaustion prevention is becoming an increasingly overwhelming problem not only in education ${ }^{23,24}$. The adoption of a multilateral approach to burnout was described by Dawkins et al in a study performed on surgeons ${ }^{25}$. These authors also emphasized that the administration must be based on the requirements of individuals, the structure of training and changes in the health or education system ${ }^{25}$.

Initiatives to prevent the burnout are often focused on people, rather than on the systemic approach to the problem. The most frequent actions implemented in this field have indirectly required teachers to adapt themselves to various changes in the occupational or social environment, namely to become more resilient and cope with stressors ${ }^{11,12,24}$. However, such an individualistic approach can ignore the sources of work stressors, such as aggression, lack of staff, and austerity measures, which are often beyond an individual's control ${ }^{9,13,18,19}$.

Occupational stress has also been certified as one of the most persistent predictors of burnout, regardless of the epidemiological state, its negative action on the psycho-emotional state being described by a large number of authors, ${ }^{9,1}$.

The results of this study are important for high schools in several ways. The most important thing is that the decisions of the institution and the administration can lead to burnout or prevent it. A growing awareness of burnout as an organizational issue, not as an individual issue, and as a measure of safety and quality of teaching, is a small step in developing a healthy and successful workforce. Education, support and a change of culture at the workplace will be essential, the ability to identify and express their problems would be the main ways to reduce the level of emotional exhaustion ${ }^{1,9,12,19}$. Implementing this positive change will now give us the best chance to deactivate this time bomb, but also to protect the teachers in the future ${ }^{16,26}$.

Finally, it should be noted that the recent COVID-19 pandemic and its impact on high school education have required from the teachers in the Republic of Moldova, in a very short time, to change their usual work, as well as to adopt new technological platforms for e-learning. These sudden changes, as well as the uncertain differentiation between homework and work, have created additional stressors for teachers.

\section{Limitations of the study}

The current study has some limitations. All data were based on self-reports. In the future, research should be implemented on additional and more objective methods of mismatch between the employee and the work environment (eg assessment of the physical factors of the occupational environment). Also, this research included a sample of teachers only from the Republic of Moldova, therefore the sociocultural context can also be a significant factor. The specifics for education systems in different countries, working conditions and widely defined rewards, as well as the dominant values of employees, must be taken into account.

\section{Conclusions}

In this first survey conducted on teachers before and during the COVID-19 pandemic, a high level of burnout could be observed as a result of sudden changes in teaching methods, as well as lack of physical contact with students and colleagues. The female respondents had higher risk of getting personal and work-related burnout, and this may be related to the dual role the females play in running the house, apart from working in the high school. The common concerns seem to be related to the quality of the lesson, as well as to one's own ability not to meet the requirements related to e-learning. Also, high levels of burnout before the pandemic have led to an increase in teachers' emotional exhaustion. Occupational stress has also been shown to be a strong predictor of the occupational burnout, especially in young specialists.

We believe that ensuring the well-being of teachers is essential in these times, that are unfavorable for the health sector, in particular, and for society in general. Interventions at the organizational level, such as promoting preventive resilience strategies and providing a friendly environment for workers, will go a long way in reducing stress and burnout in schools.

\section{Author Contributions:}

Conceptualization, D.C. and S.C.; methodology, R.D.; software, D.C.; validation, S.C.; formal analysis, 
D.C and G.F.; investigation, D.C and V.M.; resources, V.M; data curation, D.C.; writing-original draft preparation, D.C.; writing-review and editing, D.C, S.C, G.F.; visualization, S.C.; supervision, F.G.; project administration, S.C. All the authors have read and agreed with the final version of the article.

\section{Compliance with Ethics Requirements:}

"The authors declare no conflict of interest regarding this article"

"The authors declare that all the procedures and experiments of this study respect the ethical standards in the Helsinki Declaration of 1975, as revised in 2008(5), as well as the national law. Informed consent was obtained from all the respondents included in the study"

"No funding for this study"

\section{Acknowledgements:}

None

\section{References}

1. Kim LE, Asbury K. 'Like a rug had been pulled from under you': The impact of COVID-19 on teachers in England during the first six weeks of the UK lockdown. Br J Educ Psychol. 2020; 90(4):1062-1083.

2. Department for Education of UK. Case studies: remote edu cation practice for schools during coronavirus (COVID-19). [Online]; 2020 [cited 2020, 11, 23]. Available from: https:// www.gov.uk/government/collections/case-studies-remote-education-practice-for-schools-during-coronavirus-covid-19.

3. Asbury K, Fox L, Deniz E, Code A, Toseeb U. How is COVID-19 affecting the mental health of children with special educational needs and disabilities and their families? Journal of Autism and Developmental Disorders. 2020;1(1):1-9.

4. Schleicher A. Valuing our teachers and raising their status: how communities can help. International Summit on the Teaching Profession. [Online]; 2018. Available from: https://www.oecd-ilibrary.org/docserver/9789264292697-en. pdf?expires $=1619681490 \&$ id $=$ id\& accname $=$ guest $\&$ checksu $m=753$ FA529F27905559FA2A70CC7EC5395

5. The World Bank. [Online]; 2020. Available from: https:// www.worldbank.org/en/data/interactive/2020/03/24/ world-bank-education-and-covid-19.

6. Biroul Național de Statistică. Activitatea instituțiilor de învățământ primar și secundar general în anul de studii 2019/20. [Online]; 2019 [cited 2020, 11, 23]. Available from: https://statistica.gov.md/newsview. php? $1=$ ro\&idc $=168 \& i d=6549$.

7. Matiz A, Fabbro F, Paschetto A, Cantone D, Paolone AR, Crescentini C. Positive impact of mindfulness meditation on mental health of female teachers during the COVID-19 outbreak in Italy. Int J Environ Res Public Health. 2020;1(18):1-22.
8. Moccia L, Janiri D, Pepe M, et al. Affective temperament, attachment style, and the psychological impact of the COVID-19 outbreak: An early report on the Italian general population. Brain Behav Immun. 2020;(87):75-79.

9. Favieri F, Forte G, Tambelli R, Casagrande M. The Italians in the time of coronavirus: Psychosocial aspects of unexpected COVID-19 pandemic. Lancet. 2020;12:279.

10. Davico C, Ghiggia A, Marcotulli D, Ricci F, Amianto F, Vitiello B. Psychological impact of the COVID-19 pandemic on adults and their children in Italy. Lancet. 2020;12:239.

11. Huang Y, Zhao N. Generalized anxiety disorder, depressive symptoms and sleep quality during COVID-19 epidemic in China: A web-based cross-sectional survey. Psychiatry Res. 2020; 288:112954.

12. Wang C, Pan R, Wan X, et al. Immediate psychological responses and associated factors during the initial stage of the 2019 Coronavirus disease (COVID-19) epidemic among the general population in China. Int J Environ Res Public Health. 2020;5(17):1729.

13. Brooks SK, Webster RK, Smith LE, et al. The psychological impact of quarantine and how to reduce it: Rapid review of the evidence. Lancet. 2020;395(10227):912-920.

14. Negrut N, Codrean A, Hodisan I, et al. Efficiency of antiviral treatment in COVID-19. Exp Ther Med. 2021;21:648.

15. Kabir MT, Uddin MS, Hossain MF, et al. COVID-19 pandemic from molecular pathogenesis to potential investigational therapeutics. Front Cell Dev Biol. 2020;8:616.

16. Gervais RL. Women's contribution to the workplace. Exploring resources, life-balance and well-being of women who work in a global context. Journal of Organizational Change Management. 2020;27(1):15-31.

17. Queen D, Harding K. Societal pandemic burnout: A COVID legacy. International Wound Journal. 2020;4(17):873874.

18. Cheptea D, Cociu S, Cazacu-Stratu A, Deleu R. Strategiile de prevenire și limitare a răspândirii pandemiei COVID-19. Revista de Științe ale Sănătății din Moldova. 2020;23(1):146-158.

19. García-González AM, Fermín T. Analysis of stress factors for female professors at online universities. Int J Environ Res Public Health. 2020;8(17):3-13.

20. Toffoletti K, Starr K. Women academics and work-life balance: Gendered discourses of work and care. Gender Work Org. 2016;(23):489-504.

21. Slišković A, Seršić D. Work stress among university teachers: Gender and position differences. Arh Hig Rada Toksikol. 2011;62(4): 299-307.

22. Maslach C, Jackson S. The measurement of experienced burnout. Journal of Occupational Behaviour. 1981;2(1):99-113.

23. Weiss D. The impact of event scale: revised. International and Cultural Psychology Series. 2007;10(1):219-238.

24. Mona S, Man A, Mohammadreza M, et al. The prevalence of post-traumatic stress disorder related symptoms in Coronavirus outbreaks: A systematic-review and meta-analysis. Journal of Affective Disorders. 2021;282(1):527-538.

25. Dawkins C, Burdess A. Burnout in surgeons: a ticking time bomb? Surgery (Oxford). 2020; 38(10): 659-663.

26. Messenger JC, Gschwind L. Three generations of telework: New ICTs and the (R) evolution from home office to virtual office. New Technol. Work Employ. 2016;31(3):195-208. 